\title{
METHODS OF ESTIMATION OF DEVELOPMENT CAPACITY OF PROCESSING ENTERPRISES AND PECULIARITIES OF THEIR APPLICATION
}

\section{ОСОБЛИВОСТІ ЗАСТОСУВАННЯ МЕТОДІВ ОЦІНКИ ПОТЕНЦІАЛУ РОЗВИТКУ ПЕРЕРОБНИХ ПІДПРИЄМСТВ}

UDC 338.43

https://doi.org/10.32843/infrastruct40-26

\section{Volkova Nelia}

Candidate of Economic Sciences,

Senior Instructor at Department

of Economics

and International Economic Relations

Poltava State Agrarian Academy

Zagrebelna Irina

Candidate of Economic Sciences,

Senior Lecturer at Department

of Economics

and International Economic Relations

Poltava State Agrarian Academy
The article deals with the problematic issues of assessing the capacity of processing enterprises; a methodological approach to assessing development potential is proposed. It has been found that in order to identify the amount of potential that is currently at the disposal of the enterprise and can be used for the development of the enterprise, it is advisable to evaluate it. Among the main methods of diagnostics of development potential, by means of which it is possible to carry out an assessment of the potential of development of enterprises, the analytical method consisting in determining the integrated factor indicator and the graphical method by means of constructing the polygon of potential are singled out. An integrated factor index is analyzed and a graphical method is developed on the basis of constructing a polygon of processing enterprises development potential. Groups of enterprises by the level of development potential are highlighted. The functional correlation between the ranked enterprise distributions is established using the rank correlation coefficient.

Key words: potential, potential of enterprise development, methods of estimation of development potential, analytical method, graphical method.

B cmamье рассмотрены проблемные вопросы оценки потенциала перерабаты- вающих предприятий; предложен методический подход к оценке потенциала развития. Выяснено, что для выявления объемов потенциала, который является в настоящее время в распоряжении предприятия и может быть использован для развития предприятия, челесообразно проводить его оценки. Среди основных методов диагностики потенциала развития, с помощью которых можно провести оценку потенциала развития предприятий, выделены аналитический способ, заключающийся в определении интегрированного фракторного показателя, и графический способ, с помощью построения многоугольника потенциала. Проанализированы интегрированный фракторный показатель и разработаны графический способ на базе построения многоугольника потенциала развития перерабатывающих предприятий. Выделены группы предприятий по уровню потенциала развития. Установлено с помощью коэсрфрициента ранговой корреляции фрункциональную зависимость между ранжированы делениями предприятий.

Ключевые слова: потенциал, потенциал развития предприятия, методы оценки потенциала развития, аналитический способ, графический метод.

Ефрективне і конкурентоспроможне функціонування кожного окремого переробного підприємства є практично неможливим без якісного і економічно обгрунтованого розвитку його ресурсного потенціалу. У сучасних умовах, коли значна частина господарств знаходиться у кризовому фрінансовому стані, їх важливим завданням є одержання максимальних прибутків при мінімальних витратах ресурсів. Однак, на жаль, нині значна частина підприємств все більше втрачає можливості здійснення навіть простого відтворення свого ресурсного потенціалу. Підвищення рівня ефективності використання потенціалу переробних підприємств відіграє провідну роль в успішному вирішенні економічних і соціальних завдань, досягненні головної мети виробництва - підвищення прибутковості. у даній статті оцінювання потенціалу розвитку десяти переробних підприємств з виробництва харчових продуктів Полтавської області здійснювалося за двома методичними підходами. За аналітичним способом була побудована матриця потенціалу розвитку на основі експертних оцінок: виробництво та реалізація продукції, система енергозабезпечення, матеріального постачання, фрінансово-кредитного та кадрового забезпечення, системи управління. За добутком параметричної одиничної оцінки підприємства і його рангу за аналізованим синтезуючим фрактором визначаються інтегровані (групові) факторні показники. Останні сумуються в розрізі суб'єктів господарювання, найвищий із них приймається за одиницю потенціалу розвитку. Його розраховують для інших підприємств як відношення сумарного потенціалу до його найвищого рівня, прийнятого за одиницю. Аналітичний метод розрахунків перевірявся та підтверджувався графрічним методом. За результатами обчислення площин побудованого багатокутника для кожного з підприємств числові величини розташовують у порядку зменшення і, таким чином, встановлюється запас можливостей подальшого розвитку виробництва харчової продукції. Оцінка потенціалу розвитку досліджуваних підприємств з виробництва харчових продуктів Полтавської області дозолили поділити їх на три групи: ті, які мають найвищий, середній та найнижчий рівень. Дана тематика має перспективу дослідження з напрямку розробки заходів, що дозволять стабілізувати розвиток вітчизняних переробних підприємств. Ключові слова: потенціал, потенціал розвитку підприємства, методи оцінювання потенціалу розвитку, аналітичний спосіб, графрічний меmod.

Problem statement. Today, any enterprise needs to increase its internal potential for the successful survival and stabilization of its position. Market conditions are characterized by this fact. It makes it possible to assess the availability and condition of resources on the basis of which the company is able to manage financial, production, intellectual resources, and if it uses them effectively, to ensure a smooth process of production and sale of products with the help of developed strategy.

There is a need to evaluate the potential development of the company. This is so because the degree of realization of available and potential opportunities directly influences achievement of operational, tactical and strategic goals of the enterprise. At the same time, the main characteristic of the potential in the process of such evaluation should be the value for achieving the set goals. It is necessary to use not only one, but several indicators, taking into account the nature of the criterion. This will allow to identify what kind of valuation to use: estimated, natural, or heuristic.

Analysis of recent researches and publications. Different works of many scientists were devoted to the questions of clarification of the essence and 
scientific concept of "potential", problems of its formation and optimization. We may admit: V. Avdeenko, F. Albert, I. Ansoffa, O. Anchishkin, M. Bakanov, B. Bachevsky, V. Gavva, V. Gerasymchuk, Y. Dinets, L. Dovgan, A. Zadoi, I. Zablodskaya, V. Zubkov, E. Ivanova, J. Quin, O. Kuzmin, I. Lukinova, M. Maksimov, B. Mochalova, V. Nemtsov, P. Pereva, I. Repina, O. Reshetnyak, M. Tymoschuk, R. Feshchur, S. Heyman, A. Tsigichko, D. Chernikov, D. Shevchenko and many others.

However, we should take into account the current challenges of the domestic economy in assessing the potential development of manufacturing enterprises that remain underdeveloped. The challenges remain despite the scrupulous attention to this problem of a big number of scientists, such as: O. Balatsky, A. Voronkova, I. Jain, Y. Doroshenko, Y. Kachmarik E. Krykavsky, O. Oleksyuk, Y. Petrovich, M. Pityulich, E. Popov, E. Lapin, I. Repina, O. Fedonin and others. In particular, the concept of the potential of social and economic development of companies remains debatable. That is why numerous methods of its evaluation have not been properly applied.

Formulating the purposes of the article. The purpose of the study is to develop practical recommendations for assessing the development potential of processing plants based on the analysis of the results of theoretical and methodological research and publications.

Presenting main material. A successful food processing plant must not only have current revenues, but also ensure the development of all components of the enterprise's potential. The potential reflects the level of competitiveness of the organization.

It is worth to say that a number of very important factors should be taken into account while analyzing sectorial features of capacity. Here we are talking about investigating the specifics of technological processes and organization of production, features of resources spent on production and the resulting final product. They characterize the segment groups of consumers, which buy goods of enterprises, as well as the markets in which they operate, etc.

The general evolution of the methodology of research and assessment of the potential of enterprises can be divided into two stages: the stage of spontaneous development and the stage of scientific segmentation. Each of them testifies to the different levels of economic consciousness of practitioners. For example, the first stage is characterized by a fuzzy formulation of the aim of research, although scientists and business practitioners have already understood the need to create qualitatively new management mechanisms. Such mechanisms would be able to combine domestic business planning experience with modern social and economic prospects (opportunities). The creation of mechanisms of such type is possible only on the basis of the hereditary nature of the cycles of development of economic systems. During this phase, the etiological and resource approaches to the understanding the potential of processing enterprises prevailed. First of all, it indicated the insufficient level of theoretical elaboration of the problem [1, p. 15].

However, it should be noted that the processing industry meets the needs of the population in food. In general, enterprises of this business area can be attributed to labor and material-dominant. Still, in some cases we may admit a significant impact of machines and equipment on the effectiveness of their activities. The industry is closely linked to agriculture (in the stages of first processing of raw materials), to mechanical engineering (to provide equipment). Specialization in the processing industry is developed in the stages of the technological cycle. If the first stages are close to the raw materials, then the next ones are close to the consumer.

The dynamics of market demand for the products of the processing industry (consumer goods) makes it necessary to assess the competitive potential of enterprises.

In our opinion, the most relevant to the essence of the category of "potential" will be the following ways of its evaluation:

1. Potential is characterized by an internal structure that is why there is a need for methods that can assess the existing and probable potential for development.

2. There is a need for methods that would evaluate the effects of direct and indirect effects on a food processing enterprise due to the fact that competitiveness potential is the result of synthesis of different types of potentials.

3. Based on the study of the dynamics of change (both in retrospect and in perspective) of the processing enterprise, there is a need to apply methods that would reflect the properties of the category of "potential".

4. The need to assess competitiveness is conditioned by the need to plan a strategy for the behavior of an entity in the market.

5. Changing consumer requirements and preferences, the development of science and technology are constantly gaining momentum. They complicate the formation of long-term strategy. However, it is enough to determine the competitive position and direction of development of the business entity and the number of indicators of competitiveness that has arisen since the beginning of market relations.

Potential management is associated not only with the definition and with usage, but with the formation and development of its properties that are required to achieve the desired goal. There is a need to develop and implement a comprehensive methodology for evaluating the capacity of processing plants under these conditions. This methodology will be based on a system of reasonable indicators, criteria, and 
parameters for the development of all components of the potential and also take into account the evaluation of the effectiveness of the processes of management.

It is necessary to carry out its evaluation in order to identify currently available amount of potential and which can be used for the development of the enterprise.

Assessment of development potential is about determining the level of its competitiveness or determining the ability of an enterprise to adapt in a changing external environment, its flexibility.

Applied aspects of potential assessment and diagnostics can be distinguished:

1) by the directions of usage of proper tool: current and prospective planning of activity and development; operational and strategic management of activity and development.

2) by the object level: business, enterprise, integral property complex, functional media systems, partial elements and their systems.

Capacity diagnostics are used most often to monitor the current capabilities of an enterprise and evaluate individual aspects of its operations and business results. Monitoring is defined as "a system of continuous control of the implementation of internal business processes and competencies in order to identify the results achieved - expected results" in this approach.

The main method which can be used in order to evaluate the potential of the enterprise development is the analytical method. It allows to determine the integrated factor and graphical method by building a polygon of potential.

We have selected 10 food processing companies. Their products fill the consumer basket of the average citizen in Poltava.

In our opinion, the assessment of the development potential of processing enterprises should be carried out both analytically and graphically. The results obtained by two methods should be compared to more accurately assess of the development potential of processing plants.

The analytical method (Table 1 ) is used to develop a matrix of development potential, which provides conditional expert assessments of the state of various factors of the investigated enterprise. A team of experts among the employees of the enterprise determines output.

Table 1

Matrix of general development potentials of processing enterprises in Poltava region

\begin{tabular}{|c|c|c|c|c|c|c|c|c|c|c|c|}
\hline \multirow{2}{*}{$\begin{array}{l}\text { Synthesizing factor } \\
\text { of potential }\end{array}$} & \multicolumn{10}{|c|}{ Enterprises } & \multirow{2}{*}{$\begin{array}{l}\text { Rank } \\
\text { of the } \\
\text { factor }\end{array}$} \\
\hline & 1 & 2 & 3 & 4 & 5 & 6 & 7 & 8 & 9 & 10 & \\
\hline & \multicolumn{10}{|c|}{ Parametric expert evaluation of the enterprise } & \\
\hline $\begin{array}{l}\text { The potential of the production } \\
\text { system and sales of products }\end{array}$ & 3.9 & 4.2 & 4.4 & 4.0 & 4.5 & 4.7 & 4.1 & 3.8 & 3.9 & 4.3 & 0.23 \\
\hline $\begin{array}{l}\text { The potential of the energy } \\
\text { supply system }\end{array}$ & 3.6 & 3.5 & 3.8 & 3.7 & 3.4 & 3.9 & 3.8 & 3.7 & 3.6 & 3.8 & 0.08 \\
\hline Supply system potential & 3.5 & 3.9 & 3.8 & 3.6 & 3.8 & 3.9 & 3.8 & 3.7 & 3.8 & 4.0 & 0.16 \\
\hline $\begin{array}{l}\text { The potential of the finance } \\
\text { and credit system }\end{array}$ & 4.3 & 4.6 & 4.7 & 4.6 & 4.8 & 4.9 & 4.5 & 4.3 & 4.1 & 4.7 & 0.20 \\
\hline $\begin{array}{l}\text { The potential of the staffing } \\
\text { system }\end{array}$ & 3.6 & 3.9 & 3.9 & 4.0 & 3.8 & 4.1 & 4.0 & 3.8 & 3.7 & 4.0 & 0.19 \\
\hline \multirow[t]{2}{*}{ Management system potential } & 4.0 & 4.2 & 4.2 & 3.9 & 4.0 & 4.1 & 4.2 & 4.0 & 3.8 & 4.1 & 0.14 \\
\hline & \multicolumn{10}{|c|}{ Integral (group) factor indicator of the enterprise } & \\
\hline $\begin{array}{l}\text { The potential of the production } \\
\text { system and sales of products }\end{array}$ & 0.897 & 0.966 & 1.012 & 0.92 & 1.035 & 1.081 & 0.943 & 0.874 & 0.897 & 0.989 & - \\
\hline $\begin{array}{l}\text { The potential of the energy } \\
\text { supply system }\end{array}$ & 0.288 & 0.28 & 0.304 & 0.296 & 0.272 & 0.312 & 0.304 & 0.296 & 0.288 & 0.304 & - \\
\hline Supply system potential & 0.56 & 0.624 & 0.608 & 0.576 & 0.608 & 0.624 & 0.608 & 0.592 & 0.608 & 0.64 & - \\
\hline $\begin{array}{l}\text { The potential of the finance } \\
\text { and credit system }\end{array}$ & 0.86 & 0.92 & 0.94 & 0.92 & 0.96 & 0.98 & 0.9 & 0.74 & 0.82 & 0.94 & - \\
\hline $\begin{array}{l}\text { The potential of the staffing } \\
\text { system }\end{array}$ & 0.684 & 0.741 & 0.741 & 0.76 & 0.722 & 0.779 & 0.76 & 0.722 & 0.703 & 0.76 & - \\
\hline Management system potential & 0.56 & 0.588 & 0.588 & 0.546 & 0.56 & 0.574 & 0.588 & 0.56 & 0.532 & 0.574 & - \\
\hline Total score & 3.849 & 4.119 & 4.193 & 4.018 & 4.157 & 4.35 & 4.103 & 3.784 & 3.848 & 4.207 & - \\
\hline Capacity factor & 0.885 & 0.947 & 0.964 & 0.924 & 0.956 & 1.000 & 0.94 & 0.87 & 0.88 & 0.97 & - \\
\hline
\end{tabular}

1. LLC "TH" Khorol Factory for Baby Food";

2. PJSC "Poltavatsukor"

3. LLC "Lubensky Dairy Plant";

4. LLC "Poltava Meat Factory";

5. JSC "Poltava Bakery";
6. PJSC "Dominic";

7. State enterprise «Poltava Cereal Integrated Plant»;

8. LLC "AIA Globinsky Canning Plant "Globus";

9. LLC "UkrOliya" TM "Dikanka";

10. LLC "Piryatin Cheese Factory". 
The integrated (group) factor indicator of each processing enterprises is defined as the product of the parametric estimation unit of the processing enterprise and the rank of the synthesizing factor analyzed.

The aggregate estimate is formed by all the integrated (group) factor indicators for each processing enterprise.

The coefficient of development potential (CDP) is taken to be one for the enterprise. It has the highest total score on all integrated factor indicators. For other enterprises it is calculated as the ratio to the highest level of aggregate assessment of the leader enterprise [2, p. 137].

Therefore, we calculated the development potential of processing enterprises by analytical means. We have found that the studied enterprises can be divided by the level of development potential into three groups:

The 1st group: these are the enterprises that have the highest level of development potential. These include PJSC "Dominik", LLC "Lubensky Dairy Plant" and LLC "Piryatin Cheese Factory".

The 2nd group consists of enterprises with medium level of development potential. These are JSC "Poltava Bakery", State Enterprise "Poltava Cereal Integrated Plant" and PJSC "Poltavatsukor".

The 3rd group includes the enterprises with a low level of development potential. These are the
LLC "Poltava meat plant", LLC "TH" Khorol Factory for Baby Food", LLC "AIA Globinsky Canning Plant "Globus" and LLC "UkrOliya" TM "Dikanka".

We will diagnose the development potential of processing enterprises in the Poltava region by the graphical method in order to confirm these results.

The graphical way of determining the level of development potential of the enterprise is to construct a polygon of development potential on the corresponding diagram (Fig. 1). An enterprise with the highest level of development potential will be matched by a polygon with a maximum area of $\mathrm{Si}$. After drawing the axes and fixing the levels of values of each factor under study on them at equal angles, the area of each polygon is calculated by the formula:

$$
S=\sum_{i=1}^{10} \frac{1}{2} \sin \Delta \mathrm{x}\left(\mathrm{a}_{i}+a_{i+1}\right)
$$

Here, $a_{i}$ is the value of the integrated factor in each of the six processing plants, with $i=6$ (six integrated factors of the enterprise potential).

The results of calculations of data concerning selected 10 enterprises are given in Table 1. Some difficulties that arise with the calculation by such a method are offset by the ability to visualize the state of the enterprise and compare it with the competitors.

The results of the enterprise development potential assessment, as defined in Table 2, make it possible to rank them by value. Here we mean

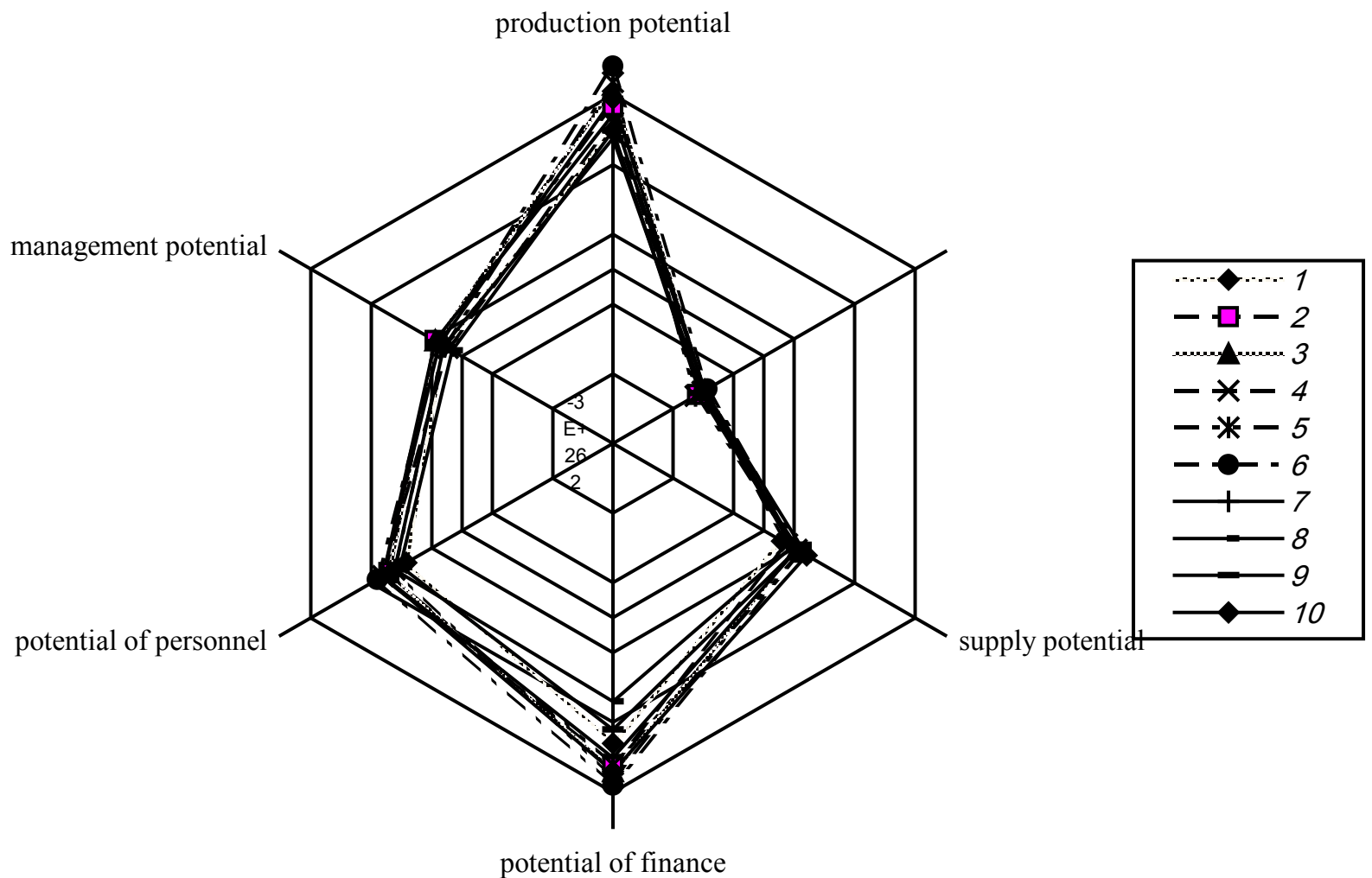

Fig. 1. Graphic representation of the comparison of selected enterprises by the potentials of development of processing enterprises in Poltava region 
The results of ranking of enterprises by the indicators of general development potentials

\begin{tabular}{|c|c|c|c|c|}
\hline \multirow{2}{*}{ Enterprise } & \multicolumn{2}{|c|}{ The value of the area of the polygon of potential } & \multicolumn{2}{|c|}{ Capacity factor } \\
\cline { 2 - 5 } & (square units) & rank & value & rank \\
\hline 1. & 0.698 & 8 & 0.885 & 6 \\
\hline 2. & 0.795 & 6 & 0.947 & 3 \\
\hline 3. & 0.820 & 3 & 0.964 & 7 \\
\hline 4. & 0.761 & 7 & 0.924 & 4 \\
\hline 5. & 0.796 & 4 & 0.956 & 1 \\
\hline 6. & 0.874 & 1 & 0.948 & 5 \\
\hline 7. & 0.795 & 5 & 0.87 & 10 \\
\hline 8. & 0.676 & 10 & 0.88 & 9 \\
\hline 9. & 0.694 & 9 & 0.97 & 2 \\
\hline 10. & 0.827 & 2 & & \\
\hline
\end{tabular}

obtaining a hierarchy of their competitive statuses, or the so-called ranked distribution (Table 1). This table shows the results of calculations of the planes of polygons constructed according to the scheme (Fig. 1) for all 10 enterprises. They are also ranked according to the values of the integrals, which numerical values are in descending order.

$$
\sum_{i=1}^{10} \Delta=\frac{360}{n}=\frac{360}{10}=36 .
$$

$\mathrm{S}_{1}=1 / 2 \times 0.5878 \times(0.897 \times 0.288+0.288 \times$ $0.56+0.56 \times 0.86+0.86 \times 0.684+0.684 \times 0.56+$ $0.56 \times 0.897)=0.698$

$\mathrm{S}_{2}=1 / 2 \times 0.5878 \times(0.966 \times 0.28+0.28 \times 0.624+$ $0.624 \times 0.92+0.92 \times 0.741+0.741 \times 0.588+0.588 \times$ $0.966)=0.795$

$\mathrm{S}_{3}=1 / 2 \times 0.5878 \times(1.012 \times 0.304+0.304 \times$ $0.608+0.608 \times 0.94+0.94 \times 0.741+0.741 \times 0.588+$ $0.588 \times 1.012)=0.820$

$\mathrm{S}_{4}=1 / 2 \times 0.5878 \times(0.92 \times 0.296+0.296 \times 0.576+$ $0.576 \times 0.92+0.92 \times 0.76+0.76 \times 0.546+0.546 \times$ $0.92)=0.761$

$\mathrm{S}_{5}=1 / 2 \times 0.5878 \times(1.035 \times 0.272+0.272 \times$ $0.608+0.608 \times 0.96+0.96 \times 0.722+0.722 \times 0.56+$ $0.56 \times 1.035)=0.796$

$S_{6}=1 / 2 \times 0.5878 \times(1.081 \times 0.312+0.312 \times$ $0.624+0.624 \times 0.98+0.98 \times 0.779+0.779 \times 0.574+$ $0.574 \times 1.081)=0.874$

$\mathrm{S}_{7}=1 / 2 \times 0.5878 \times(0.943 \times 0.304+0.304 \times$ $0.608+0.608 \times 0.9+0.9 \times 0.76+0.76 \times 0.588+0.588 \times$ $0.943)=0.795$

$\mathrm{S}_{8}=1 / 2 \times 0.5878 \times(0.874 \times 0.296+0.296 \times$ $0.592+0.592 \times 0.74+0.74 \times 0.722+0.722 \times 0.56+$ $0.56 \times 0.874)=0.676$

$S_{9}=1 / 2 \times 0.5878 \times(0.897 \times 0.288+0.288 \times$ $0.608+0.608 \times 0.82+0.82 \times 0.703+0.703 \times 0.532+$ $0.532 \times 0.897)=0.694$

$\mathrm{S}_{10}=1 / 2 \times 0.5878 \times(0.989 \times 0.304+0.304 \times 0.64+$ $0.64 \times 0.94+0.94 \times 0.76+0.76 \times 0.574+0.574 \times 0.989)=$ 0.827 .

Therefore, graphical data, obtained by the first method, confirm our calculations and allow us to determine three levels of development potential of processing enterprises in Poltava region.
The results of the calculations from the table concerning the potential of development of processing enterprises of Poltava region are included in the table. In addition, in Table 2, we bring the results of calculations of the planes of polygons for all processing enterprises of Poltava region. We make the calculations according to the values of integrals, the numerical values of which are arranged in descending order.

Comparison of ranked distributions of enterprises, performed by two methods, shows their sufficient identity.

The rank correlation coefficient establishes an almost functional relationship between the two ranked enterprise distributions. This indicates the possibility of using both methods of assessing the development potential of enterprises operating in a particular market segment. Therefore, the leaders of the development potential are PJSC "Dominik", LLC "Lubensky Dairy Plant" and LLC "Piryatin Cheese Factory".

Conclusions of the study. Summarizing results of the research we conclude that management decisions should take into account the mutual influence of factors, as well as the most important criteria for assessing the impact of traits. It is necessary to distinguish from the whole a set of only those assessments that form the general criteria for assessing the quality of the enterprise.

It must be acknowledged that estimating the development potential of processing plants based on the use of the analytical method is very important. It determines the integrated factor and graphical method. Building a polygon of potential is affordable and effective. The introduction of this methodology makes it possible to compare the synthesizing factors of the enterprise potential and to develop measures to increase the efficiency of the use of the development potential.

\section{REFERENCES:}

1. Hryhorev V.V., Ostrovkyn Y.M. (1998) Otsenka stoymosty predpryiatyi: ymushchestvennyi pokhod 
[Valuation of companies: property campaign]. Moscow: Delo. (in Russian)

2. Bachevskyi B.le., Zablodska I.V., Reshetniak O.O. 2009Potentsial i rozvytok pidpryiemstva [Potential and development of the enterprise]: navch. posibnyk. Kyiv : TsUL. (in Ukrainian)

3. Tymoshchuk M.R., Feshchur R.V. (2003) Otsiniuvannia potentsialu rozvytku pidpryiemstva [Assessment of enterprise development potential]. Visnyk Derzhavnoho universytetu "Lvivska politekhnika". Ser.: Menedzhment ta pidpryiemnytstvo v Ukraini: etapy stanovlennia i problemy rozvytku. № 494. 153-160.

\section{БІБЛІОГРАФІЧНИЙ СПИСОК:}

1. Григорьев В.В., Островкин И.М. Оценка стоимости предприятий: имущественный поход.. М.: Дело, 1998. 224 с.

2. Бачевський Б.Є., Заблодська І.В., Решетняк О.О. Потенціал і розвиток підприємства: навч. посібник. К.: ЦУЛ, 2009. 400 с.

3. Тимощук М.Р., Фещур Р.В. Оцінювання потенціалу розвитку підприємства. Вісник Державного університету «Львівська політехніка»-. Сер.: Менеджмент та підприємництво в Україні: етапи становлення і проблеми розвитку. 2003. № 494. С. 153-160. 